\title{
The relationship between family structure and exclusive breastfeeding prevalence in Nicaragua
}

\author{
Henry Espinoza, MD, MPH.(1)
}

\begin{abstract}
Espinoza $\mathrm{H}$.
The relationship between family structure and exclusive breastfeeding prevalence in Nicaragua.

Salud Publica Mex 2002;44:499-507.

The English version of this paper is available too at: http://www.insp. mx/salud/index.html

A bstract

Objective. To examine the relationship between family structure and the prevalence of exclusive breastfeeding (EBF) in N icaragua. Material and Methods A subset of the $\mathrm{N}$ icaraguan Demographic and Health Survey conducted in 1998 was obtained by selecting all last-born infants less than 4 months old at the time of the survey.W eighted chi-squared and multivariate logistic regression analyses were used to examine the asso ciation. Results. Interviewee women heads of household and inter viewee women whose husbands were the heads of the household had a significantly lower prevalence of EBF. Exposure to the health care system was not related to EBF. Conclusions New approaches are needed to promote that men support women's decisions to breastfeed. Health institutions should effectively communicate the benefits of breastfeeding on both the mother and the child.The English version of this paper is available to 0 at: http://www.insp.mx/salud/index.html
\end{abstract}

Key words: breastfeeding; determinants; family; LatinA merica; $\mathrm{N}$ icaragua; prevalence

\author{
Espinoza $\mathrm{H}$. \\ La relación existente entre las prácticas de lactancia \\ materna exclusiva y la estructura \\ de la familia nicaragüense. \\ Salud Publica Mex 2002;44:499-507. \\ El texto completo en inglés de este artículo también \\ está disponible en: http://www.insp.mx/salud/index.html
}

\section{Resumen}

Objetivo. Examinar la relación existente entre la estructura de la familia y la prevalencia de la práctica de lactancia materna exclusiva (LME) en N icaragua. Material y métodos Se tomó una submuestra de la Encuesta $\mathrm{N}$ icaragüense de Demografía y Salud de 1998, seleccionando a todos los infantes últimos nacidos menores de cuatro meses al momento de la encuesta. Se procedió a hacer un análisis bivariado con la prueba estadística de ji cuadrada y multivariado a través de regresión logística. Resultados. Se encontró que la prevalencia de LME es más baja entre las mujeres jefas de hogar y entre las que vivían en hogares cuyo jefe era el esposo de la entrevistada. El contacto con los servicios de salud no se relacionó con la LME. Conclusiones La promoción de las prácticas de alimentación infantil debería dirigirse también a los hombres, para que las mujeres que amamantan puedan ser apoyadas por sus parejas. Las instituciones de salud deben comunicar efectivamente a las mujeres los beneficios de la lactancia exclusiva al seno materno. El texto completo en inglés de este artículo también está disponible en:http://www.insp.mx/ salud/index.html

Palabras clave: A mérica Latina; lactancia; determinantes; familia; N icaragua; prevalencia

(1) Population Council, 0 ficina Regional para A mérica Latina y El C aribe.

Received on: December 3,2001 - Accepted on: Juny 25, 2002

Address reprint request to: Henry Espinoza, Population Council. 0 ficina Regional para A mérica Latina.

Escondida N o. 110, 64000, colonia Villa Coyoacán, México, D.F., México.

E-mail: hespinoza@popcouncil.org.mx 
T he World Health Organization (WHO) recommends that the optimal way to feed an infant from birth during the first 4 to 6 months* of life is providing him/ her exclusively with breast milk. ${ }^{1}$ In Nicaragua, the Ministry of Health recommends exclusive breastfeeding for the first six months of life. ${ }^{2}$ After this period complementary food should be introduced; however, breastfeeding should continue up to and beyond the child's second birthday. ${ }^{1}$ Although the $\mathrm{WHO}$ recommendation has been in effect for more than two decades, the majority of women in the world do not comply with it. ${ }^{3}$ This discrepancy has motivated researchers to explore the elements that either impede or motivate women to select and practice exclusive breastfeeding.

The theoretical framework used in this study assumes that family support is an underlying determinant of exclusive breastfeeding practice. ${ }^{4}$ Women's scientific knowledge of breastfeeding plays a secondary role. Family structure creates and supports the rules for child feeding practices. ${ }^{5}$ According to this behavioral model, social expectations often play a greater role in determining a woman's infant feeding practice than her individual knowledge. ${ }^{5,6}$

A woman's close relationships are important in shaping her views on infant feeding behavior. How much a particular woman is influenced depends on the type of relationship and the amount of support. Specific family members influence varies from place to place, ${ }^{7}$ and the woman's decision to exclusively breastfeed may be restricted by the conditions imposed by the household leader or other family members. ${ }^{8}$

In Nicaraguan society, the family is "like an extended web" ${ }^{\prime \prime}$ rather than a nuclear family consisting of husband, wife, and children. Very little is known about the influence of Nicaraguan family structure on the way infants are fed.

Using a national representative database, ${ }^{10}$ this study provides evidence generalizable to the Nicaraguan population about the practice of exclusive breastfeeding. Our study aimed to answer the following questions:

1. Does a Nicaraguan woman's breastfeeding behavior correspond to the structure of the household in which she lives?

2. What are other determinants of exclusive breastfeeding in Nicaragua?

\footnotetext{
* In April 2001, the WHO's Expert Consultation Team changed this recommendation, stating that women should exclusively breastfeed their children for the first six months of life (WHO, Note for the Press $N^{\circ} 7$ ).
}

\section{Material and Methods}

The data source is the 1998 Nicaraguan Demographic and Health Survey (DHS). This study used a multistage cluster sampling design based on a nationally representative sampling framework developed by the Nicaraguan National Institute of Statistics and Macro International. The DHS used three data collection instruments, administered at the household level, to collect information on fertility, family planning, and overall maternal and child health status. ${ }^{10}$ Two were administered to women aged 15-49 with children under 5 years of age and included several questions about infant feeding practices. The third questionnaire was administered to men 15-49 years old and included only family planning questions.

The sample included 11528 households and was representative at the provincial, regional, and national levels. The total response rate for women was $92.1 \%$ with similar participation for rural and urban regions.

For this study, a subset of the master file was created by selecting the last born children aged 0 to 3 months ( $n=463$ cases). Statistical analysis consisted of frequency and contingency table analysis, and weighted* chi square tests to assess the significance of the relationship between the predictor and respondent variables. Similar procedures were used to identify potential confounder variables, and other potential predictors reported by other researchers. ${ }^{7,11,12}$ To control for 'child's age,' the data were analyzed for two age groups. First, the age group of 0 to 3 months was assessed, as recommended by WHO guidelines. ${ }^{13}$ Second, the infants who were younger than 30 days were separated out, and the analyses were conducted again for the remaining group of 1 to 3 months. Because the median duration of exclusive breastfeeding was 21 days, (this is the age at which $50 \%$ of these infants are being exclusively breastfed), it was expected that some predictors might not be the same for both age groups. As the child ages, the feeding methods are affected by different factors. ${ }^{12,14}$ All analyses were conducted using the statistical program SPSS 8.0 for Windows.

Definitions of variables for this study

- Exclusive Breastfeeding: This variable was based on the 24-hour recall checklist questionnaire. It measured whether the child did or did not receive any food or liquid, other than breastmilk, during the 24 hours before the interview.

* Sample weight 
- Head of the Household: This variable measured the position of the interviewee in relation to the household head. It was coded in the following five categories:

a) 'A female relative is' the head of the household.

b) 'Her partner or husband is' the head of the household.

c) 'A male relative is' the head of the household.

d) 'The index mother is,' the interviewee is the head of the household, which also includes a woman who said her partner or husband was the head of the household but he was not living in the house at the time of the survey.

e) 'A non-relative -regardless gender. A person who is not a family member- is' the head of the household.

- Exposure to the health care system: This variable was a summary measure of three variables: prenatal care provided by the health care system, delivery place either at a private or public health facility, and whether the index child had a health card (reflecting exposure to the immunization program.). We coded this variable into three categories:

a) 'No' meant the woman did not receive prenatal care, she delivered at home, and she reported that her child did not have a health card.

b) 'Yes, at least at one point' meant the woman had at least one contact with the health care system at one point, which occurred either during the last pregnancy or at the time of delivery or afterwards, by having reported the child had a health card.

c) 'Yes, at three main points' means the woman had three contacts with the health care system at three key moments; at least one prenatal care visit, she delivered at a health care facility, and she reported or showed the child's health card.

- Parity: This variable was coded as 'no previous' if the index child was the only one ever delivered.

- Toilet: This variable was a proxy variable for social economic status. We coded it into the following three categories:

a) 'None' meant not having a latrine or toilet and was equivalent to being extremely poor.

b) Having a 'latrine' was considered as being poor.

c) Having a 'flush toilet' classified the person as a non-poor individual.

\section{Results}

Of the 463 women of childbearing age whose index child was three months old or less, $29.5 \%$ were exclusive breas- tfeeders, $61.4 \%$ were partial breastfeeders, and $9.1 \%$ had already weaned their infants.

The demographic characteristics of the sample are described in Table I. Men, irrespective of the relationship with the index woman, headed $69.2 \%$ of the households. In over half the cases the man was the woman's partner. A female relative of the interviewed women headed $22 \%$ of the households. In $2 / 3$ of these instances the most frequent female head of household was the woman's mother. Three point five percent of participants reported that the family head was not a relative.

Women who were heads of households were less likely to be teenagers and had smaller families. About half of these women were working outside the home. Almost half were single mothers. More than two thirds lived in urban areas ( $p<0.001$ for all these values). These women did not differ from women in the other household structure categories regarding prenatal care, having a child with a health card, and their number of children under 5 years.

Nearly $20 \%$ of the women in the sample had no education. Of those who reported having made a prenatal care visit during the index pregnancy $(81 \%)$, half of them claimed having made 3-7 visits. Twenty percent of the infants were reported as not being weighed at birth (data not shown on tables). Virtually all these cases were born at home in rural areas, and their mothers had a lower education level and lower socioeconomic status, compared to mothers of infants who were weighed after delivery. The analysis of the remaining $80 \%$, who were weighed at birth, showed no relationship between weight at birth and subsequent exclusive breastfeeding.

The results of the weighted chi square tests for the bivariate models are displayed in Table II. These tests revealed significant differences between the categories of household head and exclusive breastfeeding. The relationship is sustained in the multivariate model (See Table III.) and fully explained in the next section. Region, socioeconomic status, and sex of the child were also significantly associated with exclusive breastfeeding practice. (The adjusted OR and $95 \% \mathrm{CI}$ are provided in table III for both age groups. P values are reported there for significant associations only.

\section{Discussion}

The data obtained from this analysis provide evidence that in Nicaragua, family structure is significantly related to the prevalence of exclusive breastfeeding. Women who reported that they were the heads of their households were less likely to exclusively breastfeed compared to those living under the familial authority 
Table I

\section{General Characteristics of the Sample*}

\begin{tabular}{|c|c|c|}
\hline Name of variables, values and labels & Frequency & $\%$ \\
\hline Exclusive breastfeeding 'Yes' & 136 & 29.5 \\
\hline \multicolumn{3}{|l|}{ The head of the household is } \\
\hline A female relative & 93 & 20.2 \\
\hline The woman's husband or partner & 175 & 37.8 \\
\hline A male relative & 146 & 31.5 \\
\hline The index mother & 33 & 7.1 \\
\hline A non relative & 16 & 3.4 \\
\hline
\end{tabular}

Woman's age: less than 19 years old

$134 \quad 29.0$
Woman's education

\begin{tabular}{lrr} 
N one & 83 & 18.0 \\
\hline Some elementary & 153 & 33.0 \\
\hline Complete elementary & 172 & 37.0 \\
\hline Complete junior high or more & 55 & 11.9
\end{tabular}

\begin{tabular}{lrr} 
Marital status 'single mother' & 94 & 20.4 \\
\hline $\begin{array}{lrr}\text { Working status } \\
\text { N o work }\end{array}$ & 329 & 72.0 \\
\hline W orking at home (earning cash) & 28 & 6.1 \\
\hline W orking outside the home & 100 & 21.9
\end{tabular}

Health care system related variables

$\begin{array}{lll}\text { Prenatal care during the last pregnancy 'yes' } & 377 & 81.0\end{array}$ Number of women with 3 to 7 prenatal care visits $\quad 227 \quad 49.8$ Place of delivery

\begin{tabular}{lrr} 
At home & 152 & 32.8 \\
\hline At a government health facility & 279 & 60.5 \\
\hline At a private clinic & 31 & 6.7
\end{tabular}

\begin{tabular}{|c|c|c|}
\hline Child has a health card 'yes' & 336 & 74.3 \\
\hline Delivered by cesarean operation 'yes' & 69 & 14.9 \\
\hline Use of modern contraceptive methods 'yes' & 98 & 21.2 \\
\hline Parity'no previous child' & 145 & 31.4 \\
\hline \multicolumn{3}{|l|}{ Family size } \\
\hline Less than 4 members & 71 & 15.3 \\
\hline Five to seven & 150 & 32.4 \\
\hline More than 8 members & 242 & 52.3 \\
\hline Place of residence urban 'yes' & 265 & 57.3 \\
\hline \multicolumn{3}{|l|}{ Region } \\
\hline Pacific & 263 & 56.8 \\
\hline Central & 159 & 34.4 \\
\hline Atlantic & 41 & 8.8 \\
\hline
\end{tabular}

Toilet

\begin{tabular}{lrr} 
N one & 85 & 18.5 \\
\hline Latrine & 291 & 63.1 \\
\hline Toilet & 85 & 18.4
\end{tabular}

Child's sex 'female'

228

49.4

$(n=463)$

* Selection criteria: index child less than 3 months old
Table II

Weighted Chi Square Test Bivariate Model Results for the INDEPENDENT Variables AND Exclusive Breastfeeding 'Yes' Outcome

Name of variable and categories

Head of the household is

\begin{tabular}{|c|c|c|c|c|c|}
\hline A female relative & 83 & 38.6 & 0.024 & 73 & 35.6 \\
\hline Her partner & 161 & 29.8 & & 143 & 27.3 \\
\hline A male relative & 130 & 31.5 & & 117 & 29.9 \\
\hline The index mother & 32 & 18.8 & & 31 & 19.4 \\
\hline A non relative & 14 & 64.3 & & 9 & 55.6 \\
\hline
\end{tabular}

Woman's age

\begin{tabular}{lllllll} 
Less than 19 & 119 & 31.9 & 0.902 & 105 & 29.5 & 0.928 \\
\hline 20 or more & 301 & 32.6 & & 270 & 30.0
\end{tabular}

Woman's education

\begin{tabular}{|c|c|c|c|c|c|c|}
\hline None & 79 & 35.4 & 0.001 & 70 & 32.9 & 0.004 \\
\hline Some elementary & 140 & 44.3 & & 120 & 4.8 & \\
\hline Complete elementary & 151 & 23.2 & & 137 & 21.2 & \\
\hline Complete junior high & & & & & & \\
\hline or more & 50 & 22.0 & & 48 & 22.9 & \\
\hline \multicolumn{7}{|l|}{1 arital status } \\
\hline Single mother & 84 & 31.0 & 0.767 & 74 & 25.7 & 0.072 \\
\hline W ith a partner & 337 & 32.6 & & 301 & 30.9 & \\
\hline \multicolumn{7}{|l|}{ Vorking status } \\
\hline No work & 303 & 33.7 & 0.363 & 274 & 32.5 & 0.178 \\
\hline $\begin{array}{l}\text { Working at home } \\
\text { (earning cash) }\end{array}$ & 24 & 41.7 & & 20 & 35.0 & \\
\hline $\begin{array}{l}\text { Working outside } \\
\text { the home }\end{array}$ & 87 & 27.6 & & 74 & & \\
\hline
\end{tabular}

Exposure to the health care system

\begin{tabular}{lrrrrrr} 
No & 37 & 35.1 & 0.002 & 30 & 26.7 & 0.013 \\
\hline Yes, at least at one point & 170 & 41.8 & & 143 & 38.5 & \\
\hline Yes, at three main points & 213 & 24.9 & & 201 & 23.9 & \\
$\begin{array}{l}\text { Use of modern contraceptive methods } \\
\text { N o }\end{array}$ & & & & & \\
\hline Yes & 344 & 34.9 & 0.030 & 298 & 31.9 & 0.094 \\
\hline
\end{tabular}

Family Size

\begin{tabular}{lrrrrrr} 
Less than four members & 66 & 18.2 & 0.018 & 59 & 18.6 & 0.110 \\
\hline five to seven & 131 & 32.8 & & 115 & 30.4 & \\
\hline more than eight & 223 & 36.8 & & 201 & 32.8
\end{tabular}

Place of residence

\begin{tabular}{lllllll} 
Urban & 234 & 26.5 & 0.003 & 211 & 25.6 & 0.049 \\
\hline Rural & 187 & 40.1 & & 163 & 35.0
\end{tabular}

Region

\begin{tabular}{lrrrrrr} 
Pacific & 234 & 26.1 & 0.003 & 216 & 24.1 & 0.005 \\
\hline Central & 147 & 42.9 & & 126 & 40.5 & \\
\hline Atlantic & 39 & 33.3 & & 32 & 25.0
\end{tabular}

Toilet

\begin{tabular}{lrrrrrr} 
None & 84 & 47.6 & 0.008 & 76 & 46.1 & 0.002 \\
\hline Latrine & 259 & 29.0 & & 232 & 25.9 & \\
\hline$\quad$ Flush toilet & 75 & 26.7 & & 65 & 23.1 & \\
$\begin{array}{l}\text { Child's sex } \\
\text { Female }\end{array}$ & & & & & & \\
\hline Male & 202 & 36.1 & 0.113 & 180 & 36.1 & 0.009 \\
\hline & 218 & 28.9 & & 194 & 27.7
\end{tabular}

* See definitions of variables for explanation 


\section{Table III \\ Determinants of Exclusive Breastfeeding. Multiple Logistic Regression Analysis Results*}

\begin{tabular}{|c|c|c|c|c|c|}
\hline \multirow{2}{*}{$\begin{array}{l}\text { Name of variable } \\
\text { and categories } \\
\text { Head of the household is }\end{array}$} & \multicolumn{2}{|c|}{$0-3 m(n=427)$} & \multicolumn{3}{|c|}{$1-3 m(n=371)$} \\
\hline & $\overline{\mathrm{OR}}(\mathrm{B})$ & $95 \% \mathrm{Cl} \quad \mathrm{P}$-value & $\overline{O R}$ & $95 \% \mathrm{Cl}$ & P-value \\
\hline A female relative & 1.00 & & 1.00 & & \\
\hline Her partner & 0.48 & $0.24-0.96 \quad 0.040$ & 0.43 & $0.20-0.92$ & 0.060 \\
\hline A male relative & 0.63 & $0.33-1.26$ & 0.65 & $0.32-1.34$ & \\
\hline The index mother & 0.24 & $0.07-0.80 \quad 0.020$ & 0.27 & $0.07-0.99$ & 0.050 \\
\hline A non relative & 2.88 & $0.79-10.44$ & 2.10 & $0.46-9.5$ & \\
\hline \multicolumn{6}{|l|}{ Woman's age } \\
\hline Less than 19 & 1.00 & & 1.00 & & \\
\hline 20 or more & 1.44 & $0.81-2.56$ & 1.39 & $0.74-2.60$ & \\
\hline \multicolumn{6}{|l|}{ Woman's education } \\
\hline None & 1.00 & & 1.00 & & \\
\hline Some elementary & 1.64 & $0.86-3.13$ & 1.61 & $0.79-3.27$ & \\
\hline Complete elementary & 0.77 & $0.36-1.65$ & 0.74 & $0.32-1.71$ & \\
\hline Complete junior high or mo & e 1.160 & $0.41-3.30$ & 1.17 & $0.38-3.58$ & \\
\hline \multicolumn{6}{|l|}{ Working status } \\
\hline No work & 1.00 & & 1.00 & & \\
\hline W orking at home & 1.49 & $0.57-3.85$ & 1.120 & $0.37-3.38$ & \\
\hline Working outside the home & 0.81 & $0.44-1.51$ & 0.60 & $0.29-1.24$ & \\
\hline \multicolumn{6}{|l|}{ Exposure to the health system } \\
\hline No & 1.00 & & 1.00 & & \\
\hline Yes, at least at one point & 1.86 & $0.81-4.3$ & 2.79 & $1.04-7.47$ & 0.040 \\
\hline Yes, at three main points & 1.07 & $0.43-2.6$ & 1.67 & $0.58-4.79$ & \\
\hline \multicolumn{6}{|c|}{ Use of modern contraceptive methods } \\
\hline No & 1.00 & & 1.00 & & \\
\hline Yes & 0.80 & $0.41-1.54$ & 0.81 & $0.41-1.58$ & \\
\hline \multicolumn{6}{|l|}{ Family size } \\
\hline Four or less & 1.00 & & 1.00 & & \\
\hline Five to seven & 1.50 & $0.66-3.40$ & 1.36 & $0.55-3.35$ & \\
\hline More than eight & 1.50 & $0.65-3.50$ & 1.20 & $0.47-3.07$ & \\
\hline \multicolumn{6}{|l|}{ Place of residence } \\
\hline Urban & 1.00 & & 1.00 & & \\
\hline Rural & 0.96 & $0.53-1.74$ & 0.72 & $0.37-1.40$ & \\
\hline \multicolumn{6}{|l|}{ Region } \\
\hline Pacific & 1.00 & & 1.00 & & \\
\hline Central & 1.82 & $1.10-3.01 \quad 0.020$ & 1.82 & $1.05-3.17$ & 0.030 \\
\hline Atlantic & 0.95 & $0.41-2.20$ & 0.73 & $0.28-1.94$ & \\
\hline \multicolumn{6}{|l|}{ Toilet } \\
\hline None & 1.00 & & & & \\
\hline Latrine & 0.43 & $0.23-.81<0.001$ & 0.35 & $0.17-0.68$ & 0.002 \\
\hline Flush toilet & 0.49 & $0.19-1.26$ & 0.34 & $0.12-0.92$ & 0.003 \\
\hline \multicolumn{6}{|l|}{ Child's sex } \\
\hline Female & 1.00 & & & & \\
\hline Male & 0.75 & $0.19-1.26$ & 0.56 & $0.34-0.92$ & 0.020 \\
\hline \multicolumn{6}{|l|}{ * Model Goodness-of-Fit test } \\
\hline $\begin{array}{cc}\chi^{2} & \text { D egrees of freedom } \\
56.5 & 21\end{array}$ & $\begin{array}{l}\text { P-value } \\
<0.001\end{array}$ & $\begin{array}{c}\chi^{2} \quad \text { Degrees } \\
51.8\end{array}$ & $\begin{array}{l}5 \text { of fre } \\
21\end{array}$ & edom & $\begin{array}{l}\text {-value } \\
0.001\end{array}$ \\
\hline
\end{tabular}

of a female relative. Likewise, women who live in a home where the head of the household was her partner also tended to exclusively breastfeed less than women living in a home where the head of household was another female relative (18.8 and 29.8, respectively, versus $38.6, p<0.05)$. This relationship becomes marginal for the group of children aged 1 to 3 months ( $p=0.05$ and 0.06).

Women who reported that they were the heads of their households were significantly different in age, place of residence and working status, from women who lived in a home where another female relative was the head of the household. Compared to this last group, head of household index women tended to live in smaller families, be employed outside the home, be single, and be older. Their contacts with the health care system, however, were similar. The most likely explanation for the finding regarding breastfeeding practice is that women who are head of households might have less family support. Without this support, activities outside the home, such as having to work, might prevent exclusive breastfeeding. In Nicaraguan society, women are highly dependent on the support system formed by sisters, mothers, grandmothers, and other relatives. Strength in numbers enables families to confront economic difficulties. ${ }^{9,15,16}$ Bryant (1982) also found that in the Hispanic American community, mothers who received support from family members also had improved breastfeeding outcomes. ${ }^{17}$

Women living in a house headed by her partner, exclusively breastfed less than those women living in a house headed by another female relative. This may be explained by two factors; the first is the contextual meaning of being a male head of the household; and the second is men's attitudes towards breastfeeding. The head of the household is the person whose decision prevails. Patria Potestad, a Nicaraguan law that was in effect until 1981, recognized only fathers as heads of household, holding absolute power over the family and its possessions. ${ }^{18}$ Collinson et al (1990) also commented on the fact that many Nicaraguan men do not take responsibility for the family, leaving single women and children on their own. ${ }^{9}$ On the other extreme, a man's presence in the house can also be oppressive. Ellsberg et al., reported that about $52 \%$ of Nicaraguan women who had a child less than 5 years old at the time of the survey had been beaten at least once in their life by their husbands. ${ }^{19}$ Since 1981 several laws have been enforced to improve women's social status, family leadership, and land ownership. ${ }^{2,20-25}$ This scenario may provide some insights into the powerful position of a man over his wife, and may be particularly powerful in women's child feeding decisions if he is the family leader. 
A man's positive or negative attitudes towards breastfeeding can easily influence a woman's breastfeeding behavior. Men may disapprove of breastfeeding if they believe it will interfere with sexual activity, will make women lose their breast shape, or cause women to expose their breasts in public. ${ }^{26,27}$ The child's father, on the other hand, may be supportive of breastfeeding ${ }^{28}$ if he realizes that the economic benefits of human milk will free him from the responsibility of obtaining infant foods. ${ }^{26}$ Whatever the man's attitude towards breastfeeding is, it is likely to influence a woman's infant feeding method. Bryant (1982) explains that among Hispanics groups, just knowing the husband disapproves of breastfeeding was enough reason for a woman to avoid practicing it. ${ }^{17}$ Pérez-Escamilla et al (1995) suggested that in Honduras, women living in a home with the child's father, exclusively breastfed less than single mothers. ${ }^{7}$ Dr. Lutter, Latin American Regional Advisor on Nutrition, suggested that the presence of the child's father at home can also be negatively related to exclusive breastfeeding, because providing infant formula could be a father's way of showing support towards child feeding matters (Personal communication, May 19, 2000). Mukuria et al (1996) in Kenya, found that one way for the father to show responsibility toward the mother and child was by providing infant food product, which influenced woman's infant feeding behavior. ${ }^{5}$

The data in the present analysis suggest that in Nicaragua the woman's partner head of household may not be a strong source of support for exclusive breastfeeding. Further studies are needed to investigate men's beliefs regarding breastfeeding practices.

Living in the Central region of Nicaragua was associated with a higher prevalence of exclusive breastfeeding, relative to women living in the Pacific region. Initially, the analysis for this variable was conducted independently adjusting only for socioeconomic status. It revealed a protective effect on exclusive breastfeeding practice of $0.54(0.33-0.87 ; p<0.001)$ in the Central region versus the Atlantic and Pacific regions of the country. In the multivariate model the relationship only holds against the Pacific region. Two explanations may be considered. First, the Pacific region is the most urbanized, industrialized and crowded zone of the country. Recent urbanization in developing countries has brought changes that may have some positive and negative impacts on infant feeding behavior. Changes such as the increasing number of women joining the labor force, women working away from homes, families depending more and more on a cash economy, women accessing education, smaller households, and the increasing number of households headed by a woman, are among the changes listed that may severely compromise the woman's time for child care activities. ${ }^{29}$ Secondly, it may be possible that some recent health interventions conducted in the area may be accountable for the higher prevalence of exclusive breastfeeding. For instance, the pioneer hospital that fully implemented the Baby Friendly Hospital Initiative is located in the Central Region; a health project developed by Save The Children reported an increase in exclusive breastfeeding prevalence from $20 \%$ at the time the program started to $63 \%$ in the closing report. ${ }^{30} \mathrm{~A}$ comprehensive study is needed to clarify the more frequent practice of exclusive breastfeeding in this area.

As expected, socioeconomic status was highly related to the outcome variable. Those who were extremely poor, equated to not having a latrine or a toilet, exclusively breastfed more than those considered not poor (having a flush toilet), in both age groups. When compared to poor women (having a latrine), extremely poor ones exclusively breastfed more in the age group 1 to 3 months.

An early study on breastfeeding prevalence developed in 1981 by WHO reported that in Guatemala, the Philippines, and Chile, higher income women had significantly lower proportions of breastfed infants. ${ }^{31}$ Forman (1984) pointed out that for the Latin American region, higher economic level was a negative predictor of full and partial breastfeeding. ${ }^{11}$ None of these publications, however, differentiated between exclusive breastfeeding and breastfeeding. Lillig and Lackey (1982) found that exclusive breastfeeding in a Mexican community was associated with extreme poverty and inability to afford infant formula. ${ }^{32}$ Pérez-Escamilla et al (1995) also reported lower socioeconomic status as a determinant of exclusive breastfeeding in Honduras and Mexico. ${ }^{7}$ So far, the main reason why most Nicaraguan women tend to exclusively breastfeed is likely to be due to its economic benefits. Nicaraguan women reported that there were several advantages in practicing breastfeeding but the only reason to exclusively breastfeed a child was economical. ${ }^{33}$ Similarly, one motivating factor to practice this infant feeding method for neighboring Honduran women was its economic advantage. ${ }^{8}$

The sex of the child was found to be another predictor of exclusive breastfeeding. Girls seem to be favored by a longer period of exclusive breastfeeding. This relationship showed up when infants less than 1 month old were excluded. Breastfeeding girls more than boys is a finding detected also in Honduras, Brazil, ${ }^{7}$ and the Philippines. ${ }^{34}$ This has been suggested to reflect the belief that a male child's growing process demands more food. ${ }^{7}$ However, this assumption has not yet been pro- 
ven. It will be important to study the causal factors of this relationship so that appropriate interventions are developed to improve care for both boys and girls.

Exposure to the health system (see definition of variables) was not related to exclusive breastfeeding during the period 0 to 3 months. The result for the age 1 to 3 months group (OR 2.79 and 95\% CI 1.04-7.47) revealed some protective effect on exclusive breastfeeding, but, this result is rather misleading. Bivariate analyses showed that the correction for the potential effects of socioeconomic status and region had no such protective effect. In both cases, those exposed either one or three times to health workers, did not have a significantly higher prevalence of exclusive breastfeeding than women who apparently had never seen health care providers. Before 1982 the health care system had been an active promoter of infant formula. ${ }^{9}$ Since then, steps were made to reverse the effect of the immense formula campaign developed during the 70s. These included the adoption of the International Code of Breastmilk Substitutes issued by WHO/UNICEF in 1981. ${ }^{13,20}$ By the time the DHS survey was conducted, 9 of the 19 Nicaraguan maternity hospitals had been certified by the WHO/UNICEF Baby Friendly Hospital Initiative, and the remaining hospitals were working towards obtaining the certification. ${ }^{30}$ Nonetheless, it was not until June 1999 that the practice of distributing infant formula to working women during their maternity leave was officially prohibited by law. ${ }^{2,35,36}$ Prior to that, up to 44 infant formula cans were given to employed women during their maternity leave. Formulas were widely distributed at the hospitals. ${ }^{35}$

Exposure to the health care system with a negative impact on breastfeeding outcomes was reported by Pérez-Escamilla et al (1996) in the analysis of the DHS 1987 from Mexico. The author suggested that at the time, Mexico had yet to implement breastfeeding promotion activities within the health system. ${ }^{12}$ The findings from Nicaragua suggest that a review of the breastfeeding and exclusive breastfeeding activities is urgently needed, particularly now, while there exists a legislative environment for the promotion and protection of breastfeeding

The 'working status'variable did not show any significant relationship with the prevalence of exclusive breastfeeding at any point in the analysis. PérezEscamilla et al (1995) suggested that working women in Mexico might have started introducing foods or liquids long before resuming their jobs, so the relationship between a negative effect of having a job and exclusive breastfeeding was not identified. ${ }^{7}$ Forman (1984) presumed that the problem resulted from the lack of a clear definition of "job."11 In the present stu- dy women were defined to be working at home or outside the home only if they reported that such activity generated income. In this subset only $26 \%$ of women were working. However, nearly half of this $26 \%$ were classified as unskilled. The 1995 Nicaraguan census reports a rate of women's employment of about $30 \%{ }^{37}$ The main unskilled jobs among Nicaraguan women reported by most authors are street vendors, domestic workers in private houses, and owners of their own small store in their homes. ${ }^{9}, 15,16,37$ These activities make up more than three quarters of the unskilled job positions. ${ }^{37}$ What women do in these jobs has been considered to be an extension of their own household activities, ${ }^{9,15}$ and they have reported themselves as having a more flexible work schedule compared to formal job schedules. This situation enables them to take care of their own children. ${ }^{15}$ In this study, the comparison between unskilled and skilled working women showed that the unskilled women exclusively breastfeed as much as non-working women. On the other hand, women with skilled jobs exclusively breastfeed less than the other two groups.

The positive relationship between the women's level of education, the use of modern contraceptive methods, the size of the family, and living in a rural or urban area with the prevalence of exclusive breastfeeding, showed up only in the two-way contingency table analysis but not in the multivariate model.

This study is limited by the lack of information regarding breastfeeding attitudes from family members or from the index woman herself. Since the criteria to define the child feeding method was the child's food intake within the last 24 hours previous to the interview, it is possible that some infants fed nonbreastmilk products intermittently may have been misclassified..$^{13}$ The associations found in this study are not causal. They require more research to better understand the complexity of the social support network and its relationship with breastfeeding practices in Nicaragua.

\section{Conclusions}

The Nicaraguan family structure is significantly associated with the prevalence of exclusive breastfeeding. Interviewee women who are heads of households and women whose partners were the heads of household were found to have a significantly lower prevalence of exclusive breastfeeding, compared to women living under the familial authority of a female relative. Women living in the Central region of the country show a significantly higher prevalence of exclusive breastfeeding than those living in the more urbanized Pacific 
region. Low socioeconomic status was a predictor of this maternal behavior. Women tend to exclusively breastfeed boys for a shorter period of time than girls. Exposure to the health care system was not a determinant of exclusive breastfeeding.

Single mothers leading a household should be considered a high priority for breastfeeding support strategies. It is recommended to include the woman's partner as a target of breastfeeding programs within a broader infant feeding educational intervention. This may require conducting studies to better understand Nicaraguan men's attitudes towards breastfeeding practices, and their potential impact on women's breastfeeding decisions. Furthermore, it may be necessary to develop appropriate messages and educational techniques, as well as indicators to measure the impact of men's participation in breastfeeding. Comprehensive analyses are needed to clarify the reasons why there is a significantly higher prevalence of exclusive breastfeeding in the central region. Infant feeding messages should emphasize boys and girls as equal beneficiaries of exclusive breastfeeding and subsequent complementary feeding. It is necessary to review the current educational strategies so that health institutions can improve the way they communicate to women the benefits of breastfeeding.

\section{Acknowledgements}

I am grateful to Doctor Chessa Lutter, of the Pan American Health Organization, Washington, D.C., and Doctors Teresa González de Cossío and Juan Rivera Dommarco, of the National Institute of Public Health, Cuernavaca, Morelos, Mexico, for their valuable input to this manuscript.

\section{References}

1.W orld Health 0 rganization. Joint W HO /U N IC EF Meeting on Infant and Young $\mathrm{C}$ hild Feeding. Statement and Recommendations. G inebra, Switzerland:W orld Health 0 rganization, 1979.

2. Ley de promoción, protección y mantenimiento de la lactancia materna y regulación de la comercialización de sucedáneos de la leche materna [Law to promote, protect and sustain breastfeeding, and to regulate breastmilk substitutes]. Managua, N icaragua: La G aceta1999, June 28; No 122.

3. World Health O rganization. The W orld Health Report. Ginebra, Switzerland:W orld Health O rganization, 1998.

4. Lutter CK. Breastfeeding promotion: Is its effectiveness supported by scientific evidence and global changes in breastfeeding behaviors? Adv Exp Med Biol 2000;478:355-368.

5. Mukuria AG, Bentley M, Kogi-Makau W, C aulfield L, Bandeen-Roche K. Early complementary feeding: The role of social support networks. In:
W ellstart International's Expanded Promotion of Breastfeeding Program. W ashington, DC:W ellstart International,1996.

6. Hornik R. Alternative models of behaviors change. En:W asserheit JN , ed. Research Issues in Human Behavior and ST D s Era.W ashington, DC: A merican Society for Microbiology, 1991:201-218.

7. Pérez-Escamilla R, Lutter CK, Segall A M, RiveraA,Treviño-Siller S, Sanghvi T. Exclusive breastfeeding duration is associated with attitudinal, socioeconomic and biocultural determinants in three Latin American Countries. J N utr 1995;125:2972-2984.

8. Cohen RJ, Brown KH, Landa L, D ewey KG. Promoting exclusive breastfeeding for 4-6 months in Honduras: Attitudes of mothers and barriers of compliance. J Hum Lact 1999;15:9-18.

9. Collinson H, Broadbent L, Daphne D, G insburg E, N uttall C, Somers J, ed. Women and revolution. N ueva Jersey: Zed Books, 1990.

10. Demographic and Health Survey. Encuesta $N$ acional de Demografia y Salud, N icaragua. C alverston, Maryland: Macro International, 1998.

11. Forman MR. Review of research on the factors associated with choice and duration of infant feeding in less developed countries. Pediatrics 1984;74:667-693.

12. Pérez-Escamilla R, Maulen-Radovan I, D ewey K. The association between cesarean delivery and breastfeeding outcomes among Mexican women. Am J Public Health 1996;86:832-836.

13. World Health 0 rganization. Indicators for assessing breast-feeding practices. Report of an informal meeting. Geneva, Switzerland:W orld Health O rganization, 1991.

14. Pérez-Escamilla R, Segura-Millán S, Pollitt E, D ewey K. D eterminants of lactation performance across time in an urban population in Mexico. Soc Sci Med 1993;37(8):1069-1078.

15. Largaespada C. Soy la última en comer : crisis económica y familiar de las mujeres trabajadoras de Managua, $\mathrm{N}$ icaragua [I am the last one to eat: Economic and familial crisis among working women in Managua, $\mathrm{N}$ icaragua]. Managua:Editorial N ueva N icaragua, 1993.

16. Lamontagne JF, Engle PL, Zeitlin MF. Maternal employment, child care, and nutritional status of 12-18-month-old children in Managua, N icaragua. Soc Sci Med 1998;46(3):403-414

17. Bryant CA.The impact of kin, friend and neighbor networks on infant feeding practices: Cuban, Puerto Rican and Anglo families in Florida. Soc Sci Med 1982;16: 1757-1765.

18. Latin American W orking Group. Central American women speak for themselves.Toronto, 0 ntario, C anada: Latin A mericanW orking G roup, 1983. 19. Ellsberg MC, Peña R, Herrera A, Liljestrand J,W inkvist A.W ife abuse among women of childbearing age in $\mathrm{N}$ icaragua. Am J Public Health 1999;89(2):241-244.

20. Ley de promoción de la lactancia materna [Law to promote breastfeeding]. Managua, N icaragua: La G aceta 1981, D ecember 15; N 0292.

21. Ley de reforma agraria [Law for the agricultural reform]. Managua, N icaragua: La Gaceta 1981, 0 ctober 2; N 0222.

22. Ley 0 rgánica del Ministerio de Salud [Law for the Ministry of Health functions]. Managua, N icaragua: La Gaceta 1982, May 3; N 0102.

23.Ley reguladora de las relaciones entre madre, padre e hijos [Law to regulate relations between mothers, fathers, and children]. Managua, $\mathrm{N} \mathrm{i-}$ caragua: La Gaceta 1982, July 3; N 0156.

24. Ley de alimentos [Law of nurturing]. Managua, N icaragua: La Gaceta 1992, March 24; N 057.

25. Código de la niñez y la adolescencia [The code for children and adolescents] (1998, May 27). Managua, N icaragua. La Gaceta 1998, May 27; No 97. 26. Bryant CA, Coreil J, D'Angelo SL, Bailey FC, Lazarov M.A strategy for promoting breastfeeding among economically disadvantaged women and adolescents. N AAC O G's C linical Issues 1992;3(4):723-730.

27. Bentley ME, C aulfield LE, Gross SM, Bronner Y, Jensen J, Kessler LA et al. Sources of influence on intention to breastfeed among African-A merican women at entry to W IC.J Hum Lact1999;15(1):27-34. 
28. Kessler LA, Gielen AC, Diener-W est M, Paige DM. The effect of a woman's significant other on her breastfeeding decision.J Hum Lact 1995;11(2):103-109.

29.Ruel MT.U rbanization in Latin A merica: Constraints and opportunities for child feeding and care. Food N utr Bull 2000;21(1):12-24.

30. UN ICEF. Breastfeeding: A right of mothers and infants; mother and baby friendly hospitals, health centers and universities. Managua, $\mathrm{N}$ icaragua: UN ICEF, 1999.

31.W orld Health 0 rganization. C ontemporary patterns of breastfeeding: Report on theW HO collaborative on breastfeeding. Geneve, Switzerland: W orld Health O rganization, 1981.

32. Lillig K, Lackey CJ. Economics and social factors influencing women's infant feeding decision in a rural Mexican community. J Trop Pediatr 1982;28:240-247.

33. Picado Jl, 0 Ison CM, Rasmussen KM. Metodología combinada para entender la duración del amamantamiento en barrios pobres de Managua,
N icaragua [A combined methodology for understanding the duration of breastfeeding in the poor neighborhoods of Managua]. Rev Panam Salud Publica 1997;2(6):398-407.

34.A dair LS, Popkin BM, G uilkey D K. The duration of breast-feeding: How is it affected by biological, socioeconomic, demographic, health sector and food industry factors? Demography 1993;30:63-80.

35. W ellstart International. Lactancia Materna en N icaragua: diagnóstico de prácticas y promoción. Managua, N icaragua:W ellstart International,1994. 36. Las mujeres están obligadas a dar el pecho a sus hijos [W omen are mandated to breastfeed]. Managua, N icaragua: La Tribuna 1998, June 19. Available from http://www.latribuna.com.ni/cron/1998/19junio-1998/hoy/ $\mathrm{N}$ acional/4.html. Accessed January 1999.

37.Vargas 0 . Pobreza en $\mathrm{N}$ icaragua: un abismo que se agranda [Poverty in $\mathrm{N}$ icaragua is growing]. Managua, $\mathrm{N}$ icaragua: Universidad Politécnica, 1998. 